\title{
The economic theory of international supply chains: a systems view
}

Article

Accepted Version

Casson, M. and Wadeson, N. (2013) The economic theory of international supply chains: a systems view. International Journal of the Economics of Business, 20 (2). pp. 163-186. ISSN 1466-1829 doi:

https://doi.org/10.1080/13571516.2013.783514 Available at https://centaur.reading.ac.uk/29785/

It is advisable to refer to the publisher's version if you intend to cite from the work. See Guidance on citing.

To link to this article DOI: http://dx.doi.org/10.1080/13571516.2013.783514

Publisher: Routledge

All outputs in CentAUR are protected by Intellectual Property Rights law, including copyright law. Copyright and IPR is retained by the creators or other copyright holders. Terms and conditions for use of this material are defined in the End User Agreement.

\section{www.reading.ac.uk/centaur}

\section{CentAUR}

Central Archive at the University of Reading 
Reading's research outputs online 
The Economic Theory of International Supply Chains: A Systems View

MARK CASSON and NIGEL WADESON

Centre for Institutional Performance

University of Reading

Mark Casson

Department of Economics

University of Reading

Reading RG6 6AA, UK

Tel: (44) (0) 1183788227

E-mail:m.c.casson@reading.ac.uk
Nigel Wadeson

Department of Economics

University of Reading

Reading RG6 6AA, UK

Tel: (44) (0) 1183785070

E-mail:n.s.wadeson@reading.ac.uk 


\begin{abstract}
This paper offers an integrated analysis of out-sourcing, off-shoring and foreign direct investment within a systems view of international business. This view takes the supply chain rather than the firm as the basic unit of analysis. It argues that competition in the global economy selects supply chains that maximise the joint profit of all the firms in the chain. The systems view is compared with the firm-centred view commonly used in strategy literature. The paper shows that a firm's strategy must be embedded within an efficient supply chain strategy, and that this strategy must be negotiated with, rather than imposed upon, other firms. The paper analyses the conditions under which various supply chain strategies - and by implication various firm-level strategies - are efficient. Only by adopting a systems view of supply chains is it possible to determine which firm-level strategies will succeed in a volatile global economy.
\end{abstract}

Key Words: International; Strategy; Supply chain; Off-shoring; Out-sourcing; Coordination

JEL Classifications: F23, D21, L20 


\section{Introduction}

There are two main perspectives on international business (IB) strategy in the literature. The first view is firm-centred; it focuses on the competitive advantages of an individual firm, and the way that these advantages influence its strategy and structure. Building on Dunning's eclectic theory (Dunning, 1977; Dunning and Lundan, 2008), and informed by strategy and resource-based theory (Porter, 1980; Barney and Clark, 2007), the firm-centred view addresses issues of strategic alliances, cross-cultural management, subsidiary autonomy, and so on (see e.g. Birkinshaw and Young, 2005; Cantwell and Mudambi, 2005). The second view is the systems view, which focuses on the firm's environment as well as on the firm itself (Casson, 1990; Buckley and Hashai, 2004). The unit of analysis is the global production system. Building on internalisation theory (Buckley and Casson, 1998; Rugman, 1981; Hennart, 1982), the systems view examines how far linkages within the global system will be coordinated by multinational enterprises (MNEs) rather than markets. The systems view highlights the strategic importance of interactions between product flow and knowledge flow (Adler and Hashai, 2007). It identifies the characteristics of technologies, products and locations that stimulate the emergence of MNEs and encourage the flows of foreign direct investment (FDI) associated with them.

The spread of global supply chains is an important development of the last twenty years (Buckley and Ghauri, 2011; Mudambi and Venzin, 2010). In early literature supply chains were often described as multi-stage production systems (following Carlson, 1939 and Lerner, 1953). The process of differentiation, by which production is subdivided into ever smaller separable units, was described in terms of advancing specialisation, whilst the dispersion of different activities was described as 
an international division of labour (Frobel, Heinrchs and Kreye,1980). Early IB theorists recognised that there was a division of labour in the production of knowledge as well as in the production of ordinary goods (Buckley and Casson, 1976). The integrated analysis of knowledge flow and production flow has since become known as "value chain analysis" (Porter, 1980), and the application of this approach to international multi-stage production as "global value chain" theory (Sturgeon, van Biesebroeck and Gereffi, 2008).

From a systems perspective, international supply chains are the basic building blocks of the global production system; an individual supply chain for a particular product is a microcosm of the system as a whole (Antras and Helpman, 2004; Casson, 1985). Within a supply chain, the strategies of individual firms are inter-dependent; firms compete when they plan to control the same part of the chain, and co-operate when they plan to control different parts of the chain. Thus one firm's strategy may be dictated, at least in part, by another firm's strategy. If neither firm is dominant then strategy may have to be negotiated rather than imposed.

By contrast, the firm-centred view focuses on a single firm, usually identified as the "channel leader" or "orchestrator". It suggests that this dominant firm will normally possess an advantage (e.g. a key patent or brand) and will appropriate most of the rent (i.e. supernormal profit) from the chain. It takes the strategies of rival firms as given, and regards other firms in the supply chain as essentially passive. Contrary to this, the systems view suggests that advantages are context-dependent. According to the systems view, the way that firms in a supply chain behave is determined by the economic fundamentals rather than by the strategy of a leading firm. These fundamentals include trade barriers, transport costs, transaction costs, and differential 
location-specific production costs. These fundamentals apply to the industry as a whole and not just to one individual firm.

The firm-centred view is useful for business school teaching and strategy consulting, because the theory is developed from the perspective of a manager of an individual firm. The systems view, however, is more appropriate for addressing longterm global issues of concern to managers of all firms of whatever type. The systems view takes a more detached and distant view that embraces the entire global economy. It focuses, not on any individual firm, but on the entire population of firms - both existing firms and potential firms - that interact through competition and cooperation to coordinate the global economy. According to the systems view, existing types of firm can disappear, and new types of firm emerge, in response to radical changes in global conditions, such as lower trade barriers and transport costs, and reductions in transactions costs due to stronger property rights. The firm-centred view, by contrast, focuses on more incremental adjustments made by existing firms, and often ascribes these changes to innovations in business strategy instead.

Section 2 explains the key features of the systems view by reference to Coase's (1937) seminal work. Section 3 presents a systems view of international supply chain coordination. The formal model is set out in section 4 and solved in section 5. The implications of the solution are discussed in section 6. Out-sourcing and off-shoring are examined in section 7, and inward and outward FDI in section 8 . Section 9 shows that analysing supply chain strategy from the standpoint of an individual firm can be misleading because the same strategy may appear quite different to firms that are headquartered in different countries. Practical applications are discussed in section 10 and the conclusions are summarised in section 11. 
The analysis shows that optimal supply chain configuration is governed by four key trade-offs. Previous work has considered three of these trade-offs, but usually one at a time. This paper offers the first integrated rigorous account of the interplay between all four. The analysis also shows that firms of different types may co-exist at different stages of the same chain. The configuration of firms in a given chain will vary according to the economic fundamentals of the industry, including the technology embodied in the product, the institutional environment and the geography of the global economy.

\section{Principle of supply chain coordination}

The model has philosophical as well as practical significance, as it pushes forward a research agenda initiated by Ronald Coase. According to Coase (1937), firms emerge because of the costs of using the market. If there were no costs of using the market then there would be no firms. The existence of firms, on this view, cannot be merely assumed, but must be analysed as an institutional response to the costs of the market. Management is a response to transaction costs. As a result, the number, size and scope of firms are endogenous.

The boundaries of firms within a given economy must be consistent with each other. The ownership and location of different firms must be maintained in an institutional equilibrium. When the boundaries of one firm change, the boundaries of other firms must adjust. While these interdependencies are recognised in the literature they have never been formally analysed at an industry level. This paper provides a step in this direction.

In Coase's view the business system comprises a complex set of inter-related activities. Individual activities are created by a division of labour, as noted above, and 
final product is delivered to customers through supply chains that require coordination. Within each supply chain, different boundaries generate different configurations that involve different relationships between the firms within the chain. Different configurations may be championed by different firms. Competition will select the most efficient configuration; it will drive down product price, or bid up resource costs, to the point where only the efficient configuration can earn a normal profit. Efficiency will dictate how many firms operate within the supply chain, the scope of each firm's operations, and the precise location of the market boundaries between firms.

When transaction costs are high an entire supply chain may be coordinated by a single vertically integrated firm, whereas when they are low the supply chain may be coordinated entirely by arm's length trade between independent firms at each stage of production. When transaction costs are greater at certain stages of the chain than others, the stages with high transaction costs will be internalised within vertically integrated firms, and arm's trade will be confined to stages with low transaction costs.

When different stages of production are located in different countries, international supply chains are created. The more sophisticated the division of labour, the greater the degree of specialisation, greater the proliferation of activities, and the greater the number of locations at which they can be carried out. A multinational enterprise (MNE) is created when activities based in different countries are integrated within the same firm (Buckley and Casson, 1976). On this view, MNEs emerge to coordinate particular portions of supply chains, and they emerge at the same time as other firms which coordinate other parts of the same supply chain. These other firms may be single-country firms, or they may be MNEs as well. Firms controlling one 
part of a supply chain will have to negotiate with firms controlling adjacent parts of the supply chain, since neither can operate successfully without the other.

Coase's analysis therefore poses a major challenge to scholars who propose to analyse either the global economy or an individual supply chain in terms of the strategies of individual firms. From a Coasian perspective it is the supply chain as a whole, rather than the individual firm, that is the appropriate unit of analysis. To implement Coase's vision in a global context it is necessary to develop a model of efficient supply chain coordination which does not assume a given channel leader or orchestrator, but allows the channel leader or orchestrator to emerge as the firm that has championed the efficient configuration.

\section{Modelling supply chains: general observations}

Casson and Wadeson (2012) (CW hereafter) have formalised the Coasian vision within in a simple context: a supply chain comprising just $R \& D$, production and a set of customers. Their analysis reveals that the set of strategies available for international supply chain coordination is wider than supposed. Conventional theory identifies three strategies: exporting, import-substituting FDI and licensing. Supply chain analysis identifies a fourth strategy - "off-shore licensing" - which involves a firm licensing to a foreign-owned production plant located in its home country. CW argue that this strategy appears perverse only because strategic decisions are typically analysed from a licensor's point of view. When the same situation is analysed from a licensee's point of view, licensing can be interpreted as an asset-seeking strategy.

More generally, CW argue that the complexities of the IB system cannot be understood purely from the standpoint of a potential foreign investor possessing a knowledge advantage over other firms. In the modern global economy supply chains 
emerge from negotiations between firms. A firm that owns technology cannot invariably dictate the terms of the contracts used to coordinate a supply chain. Where rival technologies compete, for example, a firm with privileged access to the market may be able to dictate terms instead.

A major weakness of the $\mathrm{CW}$ model is its simplistic supply chain. This paper generalises their model so that their results appear as a special case. Two key assumptions are relaxed.

- Instead of supplying product direct to consumers, production now serves a distribution facility located in country 2 . Thus the wholesale market linking production and distribution is distinguished from the retail market linking distribution and consumers. Distribution can be either domestically owned or foreign owned.

- Foreign ownership of $\mathrm{R} \& \mathrm{D}$ is permitted, although the location of $\mathrm{R} \& \mathrm{D}$ remains fixed.

The model identifies the most efficient way of serving a given market. In the absence of externalities, the efficient strategy maximises the total profit earned by firms within the supply chain. This allows each firm to maximise its own profit conditional on the profit accruing to the other firm. If the chosen strategy did not do this it would pay the firms to agree to replace it with one that did. It is shown that the efficient strategy depends on nine key parameters. Changes in the global environment change the values of these parameters and therefore change the supply chain strategies employed by firms. Parameter values may vary between industries, thereby generating industry-specific forms of supply chain coordination. Parameter values may also change over time, guiding the evolution of the international economy by changing the supply chain strategies used in individual industries. 


\section{The model}

There are three activities - production, distribution, and R\&D - and each is carried out in a separate facility: a plant, warehouse and laboratory respectively. The consumers are at the end of the chain, and all are located in country 2 . The model is illustrated schematically in Figure 1. R\&D, represented by the triangle $R$, feeds knowledge (represented by a grey line) into production, represented by the square $P$. Product, (represented by a black line) is then consigned to distribution, represented by the square $D$, from whence it is despatched to consumers, represented by the square $C$.

\section{[Insert Figure 1 about here]}

There are just two countries: country 1 in which $R$ is based and country 2 in which $C$ and $D$ are based. Production $P$ may be located in either country. There is one firm in each country. Notation follows CW's conventions; thus to simplify the algebra it is assumed that firm 1 is headquartered in country 1 and firm 2 in country 2 . Country 2 is often described as the "host" country, because it is the country in which the market is based. It is important to note, however, that when taking a systems view, country 2 is not necessarily the country in which FDI takes place. Activities cannot be subcontracted to other domestic firms. Potentially the two firms compete with each other to control the supply chain, but they can also collaborate with each other, e.g. one firm can license technology from the other, or act as its sales and distribution agent.

It is assumed that the size of the market is fixed. The price is also fixed, either by competitive conditions, government regulation, or consumers' refusal to pay more than some maximum acceptable price. Since both price and market size are fixed, 
total revenue is fixed as well. Thus the maximisation of profit implies the minimisation of cost. It is assumed that revenue is sufficiently large that costs are always covered, and so production always takes place. Some of the costs are incurred by the facilities in which the activities are carried out, and some by the linkages between these facilities. Each facility involves a stock of assets - physical and human - which are employed to transform inputs into outputs. Their costs include wages, interest and depreciation. Linkages channel flows of resources between the facilities, and incur transport costs, knowledge transfer costs, etc.

Resource flows must be coordinated, either by firms or markets, or a combination of the two. Coordination applies to both linkages (i.e. inter-plant coordination) and facilities (i.e. intra-plant coordination). This generates the two-way classification of supply chain costs presented in Table 1. The first dimension (corresponding to the columns) concerns whether the costs are incurred by the operation of a facility or a linkage. The second dimension (corresponding to the rows) concerns whether the costs relate directly to expenditure on resources or to the coordination of resource use.

The interplay of these two dimensions generates four categories of cost. These costs vary according to the ownership and location of the facilities involved. Some costs depend on whether two facilities have the same owner or the same location, and others on whether the owner is based in the same country as the facility. The table lists the various components of cost; all have been identified from mainstream IB literature (Kotabe and Mol, 2006). For simplicity, no more than three components of cost are included in each category. Facilities costs are represented by plant production costs, whilst linkage costs are represented by transport costs and technology transfer costs. Coordination costs relating to facilities are represented by the cost of foreign 
production, which is the additional cost incurred in owning and managing a plant or warehouse from a foreign location, and the cost of managing foreign $R \& D$, which is at least as great as the cost of foreign production; these costs are sometimes referred to as the "costs of doing business abroad" due to "liability of foreignness", and include an allowance for the risk of expropriation. Coordination costs relating to linkages are particularly important: licensing costs relate to the cost of coordinating a flow of knowledge when $R$ and $P$ are owned by different firms; costs of arm's length trade are incurred when $P$ and $D$ are owned by different firms; while foreign marketing costs are incurred when $D$ is owned by a foreign firm based in country 1 . Linkage costs are assumed to be symmetrical - i.e. where reverse flows occur, the same costs apply in both directions.

Because the locations of $R$ and $D$ are fixed by assumption, their facility costs are also fixed. Only variable costs influence the choice of strategy, and so fixed costs are excluded from the model. Variable costs of production are assumed to be always positive, and transport costs and tariffs are non-negative (e.g. there are no subsidies to exports). Internalisation of both technology transfer and wholesale trade is beneficial, and so the costs of licensing and arm's length trade are positive. Costs of foreign ownership, international technology transfer and foreign marketing are non-negative.

With a two-country model there are two possible locations of each facility and two possible nationalities of ownership. There are three facilities which can be owned by either firm, and one facility - production - whose location is variable. Since each ownership decision can in principle be made independently of the others, there are $2 \times 2 \times 2=8$ possible ownership strategies. With two location strategies, each of which can be supported by any ownership strategy, there are $2 \times 8=16$ potential supply chain strategies altogether. 


\section{Solution of the model}

The model can be solved in five easy steps. However, readers not interested in the details may proceed directly to section 6 .

Step 1: Itemise the available strategies and specify their cost functions

Given that revenues are fixed, the most profitable strategy is the one with the lowest costs. The set of possible strategies is mapped out in Table 2. The first column identifies the location of production. Each strategy is given a descriptor and a number. Costs are shown in the right-hand column. Trade-related costs, $t$, are incurred whenever production is located in country 1 (because the market is in country 2 ), and technology transfer costs related to learning, $x$, are incurred whenever production is in country 2 (because $\mathrm{R} \& \mathrm{D}$ is in country 1 ). Costs of licensing, $n$, are incurred whenever production and R\&D are owned by different firms, and costs of arm's length trade, $k$, whenever production and distribution are owned by different firms. Costs of foreign marketing, $m$, are incurred whenever distribution is owned by firm 1. Costs of foreign ownership, $f$, are incurred whenever production or distribution is owned by a foreign firm, whilst costs $g \geq f$ are incurred by foreign ownership of $\mathrm{R} \& \mathrm{D}$.

\section{Step 2: Eliminate dominated strategies}

Eight strategies are dominated because their costs are always higher than those of some alternative strategy. Dominance arises for two reasons. Firstly, it never pays firm 2 to employ firm 1 as a sales agent when firm 2 owns production, and this applies wherever production is located. Secondly, it never pays firm 1 to subcontract $\mathrm{R} \& \mathrm{D}$ to firm 2 when firm 1 owns production, wherever production is located. The eight undominated strategies are listed in Table 3. 
The undominated strategies are all parsimonious in their use of foreign ownership; they use it only where significant economies of internalisation are available. Three of them are familiar from conventional IB theory: exporting to a sales agent (strategy 2), import substituting FDI in production and sales (strategy 9) and licensing (strategy 12). Two further strategies are simple variants of these: strategy 1 is a variant of strategy 2 in which distribution is controlled through a foreign sales subsidiary, whilst strategy 10 is a variant of strategy 9 in which distribution is subcontracted to a local firm.

The remaining three strategies are less familiar, because they all involve foreign investment by the firm 2 rather than the firm 1. Strategy 4 (offshore licensing) is a variant of conventional licensing (strategy 12) in which the licensee locates production country 1 rather than country 2 . Since the licensee already owns a distribution facility, this represents offshore backward integration by the licensee. Strategy 8 (fully integrated off-shoring by a host-country MNE) is a variant of exporting (strategy 1) in which firm 2 takes over the ownership role of firm 1. Firm 2 integrates backwards, not only into production but also into R\&D; in this respect strategy 8 represents an expanded version of offshore licensing (strategy 4). Strategy 16 (a fully-integrated host-country MNE off-shores R\&D) is an analogue of strategy 9 (import-substituting FDI in production and sales) with firm 2 replacing firm 1; it can also be understood as a variant of strategy 8 in which production is in country 2 rather than country 1.

In Dunning and Lundan's (2008) terminology, the three unfamiliar strategies are examples of asset-seeking FDI. They are unfamiliar because asset-seeking appears in the present context as a solution to a "market-seeking" problem. The interpretation of off-shore licensing (strategy 4) as asset-seeking was explained by CW. Firm 2 
seeks access to a new technology generated in country 1 ; it licenses the technology from firm 1 , produces locally in country 1 , and exports to its home country 2. Strategies 8 and 16 reflect a similar motivation, although in both cases R\&D is internalised rather than out-sourced as before; under strategy 8 production remains located in country 1 , whilst under strategy 16 it is relocated to country 2 .

Step 3: Express the costs of the efficient strategies relative to a suitable baseline cost.

A suitable baseline is the resource cost of producing in country 2, which is the sum of the variable cost of production in country 2 and the cost of technology transfer from country 1 to country $2, C_{0}=c_{2}+x$. Using this baseline, it is possible to define the net cost of producing in country $1, d$, as the gross cost of producing in country 1 , inclusive of transport costs and tariffs, less the baseline cost, $d=c_{1}-c_{2}+t-x$. The simplified cost functions are shown in the right-hand column of Table 3. The functions involve seven components, instead of the nine that appear in Table 2. Since the baseline cost, $C_{0}$, is common to all, however, the cost differentials depend on just six components.

Step 4: Compare costs by constructing cost differentials between each pair of strategies

For a strategy to be selected, it must be no more expensive than any other. Thus the cost differential in its favour must be non-negative with respect to each alternative strategy. Since each undominated strategy has seven alternatives, a strategy is chosen if and only if seven separate cost differentials are non-negative. Not all these inequality conditions are necessarily binding, however. The set of pair-wise cost differentials derived from Table 3 is shown in Table 4. 
Step 5: Derive the solution by combining the inequality conditions and then simplifying the results

Two key features of Table 4 are key to the solution.

- Within the northeast and south-west blocks, the diagonal terms are all functions of $d$ and $f$ alone.

- All the inequalities relating to strategies 1 and 9 involve $m$, all the inequalities relating to strategies 2 and 10 involve $k$, all the inequalities relating to strategies 4 and 12 involve $n$ and all the inequalities relating to strategies 8 and 16 involve $g$.

When these results are combined a simple pattern emerges. The condition for any given strategy to be selected is that the value of the repeated parameter associated with the strategy is less than some minimum value that depends upon the other parameters. The outcome is shown in Table 5, which identifies three scenarios, each shown in a separate column.

- In the first column the net cost advantage of location 2 is very low, $d \leq-f$, and the least-cost strategy always involves producing in country 1 . Only four strategies are in contention - 1, 2, 4, 8 - and the conditions that each must satisfy for selection are set out in the first four rows of the column.

- In the second column the net cost advantage of location 2 may be positive or negative, but is small, $-f \leq d \leq f$. Once again only four strategies are in contention - this time $1,2,12,16$ - and the conditions that each must satisfy for selection are set out in the top two rows and bottom two rows of the column. 
- In the third column the net cost advantage of location 2 is high, $d \geq f$, and the least-cost strategy always involves producing in country 2. Strategies 9, 10, 12 and 16 are in contention and the conditions that each must satisfy for selection are set out in the bottom four rows of the column. The results may be simplified further using the indicator variables $z_{1}, z_{2}, z_{3}$, which are functions of all seven parameters. The simplified results are summarised in Table 6 .

\section{Summary of the solution and discussion of its implications}

The solution shows that the ownership and location of production within an international supply chain are governed by four key trade-offs.

- Alternative forms of internalisation. Whatever the location strategy, high costs of licensing, $n$, combined with high costs of arm's length trade, $k$, encourage full integration, either by a firm based in country 1 or a firm based in country

2. High $n$ combined with low $k$ encourages the internalisation of production and $R \& D$ and the externalisation of the production - distribution link, while low $n$ and high $k$ has the opposite effect. With low $n$ and low $k$ internalisation has little influence on overall strategy.

- Alternative location strategies. This trade-off concerns the net cost differential, $d$, and the cost of foreign ownership of production, $f$. A firm headquartered in a high-cost country must trade off the saving from relocating production to a low-cost country against the penalty of being a foreign owner there.

- Trading off internalisation savings against the cost of foreign operations. This is the classic trade-off that exists when two linked facilities - production and 
$\mathrm{R} \& \mathrm{D}$, or production and distribution - are located in different countries to minimise location costs. The benefits of internalisation, $n$ or $k$, can only be achieved only at the expense of foreign ownership of one of the facilities, costing $f$ or $g$.

- Alternative firms organising integration. The final trade-off is between internalisation effected by firm 1 (based in the county where $R \& D$ is located) and internalisation effected by firm 2 (based in the country where the market is located). In an international supply chain there is a trade-off between the cost of foreign ownership of $\mathrm{R} \& \mathrm{D}, g$, incurred by firm 2 , and the cost of foreign marketing, $m$, incurred by firm 1 ; in the context of the model, a high level of $g$ discourages firm 2 from undertaking backward integration into $\mathrm{R} \& \mathrm{D}$ whilst a high value of $m$ discourages firm 1 from integrating forward into marketing. Thus when full integration is required, the relation between $g$ and $m$ governs the relative advantages of firm 1 and firm 2 in organising full integration.

Whilst the first three trade-offs are recognised, in general terms, in the IB literature, the fourth is not. Furthermore, these trade-offs are usually considered separately in the IB literature whereas the systems view shows that they are all related.

The solution above does not merely specify the boundaries of a given firm, as in conventional theory, but the ownership and location of all the firms involved in the supply chain. The model ensures that all these boundaries are consistent with each other, and that together they maximise the profit generated by the firms as a whole. The model also reveals the internal structure of each firm. This internal structure is 
adapted to the internal structures of the others. Thus solving for the supply chain structure as a whole ensures that the configurations of the different firms are compatible with each other. In particular, it ensures that they trade with each other in a well-defined set of external markets; in other words, it ensures that the internalisation decisions of different firms are compatible with each other.

Within this model there are just two possible boundary locations at which firms interface with each other: the market for technology linking $R$ and $P$, and the market for output linking $P$ and $D$. In principle both boundaries could exist simultaneously, but in practice they will not because the relevant configurations (represented by strategies 3, 6, 11 and 14) are never efficient. According to Table 7 four out of the eight efficient strategies involve two firms interfacing with each other at a single boundary, and the remaining four involve control by a single dominant firm. The model also determines whether one or both of the firms is an MNE. In two of these cases both the firms are single-country firms, and no MNE is involved, whilst in the other two cases an MNE partners with a purely national firm. If only one firm is involved, as in the other four cases, then, given the assumptions of the model, this firm is always an MNE.

Taken together, these results have important implications for:

- The number of firms involved in a supply chain;

- The internal structures of firms involved in the supply chain;

- The location of the external markets where the boundaries of the firms are positioned;

- The efficiency of outsourcing and offshoring strategies and the conditions that favour their use; 
- The relationship between FDI and multinationality, which, in a supply chain context, is not so straightforward as often assumed;

- The appropriation of monopoly profit within a supply chain - an issue that raises interesting questions about how the concept of "strategy" should be construed in IB.

These issues are examined in the remainder of this paper.

\section{Out-sourcing and off-shoring}

Off-shoring involves procuring an input from, or supplying an output to, a foreign country. Out-sourcing involves the procurement of an input from, or the supply of an output to, an independently owned facility (di Gregorio, Musteena and Thomas, 2009; Mol, 2007). With just two firms in the model, each based in a different country, outsourcing is always international, i.e. involves partnering with a foreign-owned firm.

The out-sourcing of $R \& D$ occurs when production and $R \& D$ are owned by different firms, while the out-sourcing of distribution occurs when production and distribution are owned by different firms. The out-sourcing of R\&D occurs whenever production is owned by firm 2, whilst the out-sourcing of distribution occurs whenever production is owned by firm 1 . Thus R\&D and distribution cannot be outsourced at the same time; this is a consequence of using a two-country model with $\mathrm{R} \& \mathrm{D}$ and distribution located in different countries.

Patterns of out-sourcing are indicated in the first two columns of Table 8, where $D$ denotes domestic out-sourcing and $F$ foreign out-sourcing. Altogether eight of the sixteen strategies involve R\&D out-sourcing, but six of the eight are dominated by others (see the bottom lines of the table). The two undominated strategies are offshore licensing (strategy 4) and licensing (strategy 12). Both involve production by 
firm 2; in the first case technology transfer is domestic and in the second international.

Out-sourcing of distribution follows a similar pattern, with six of the eight dominated strategies involved, compared with just two of the undominated ones. Both undominated strategies involve classic foreign market entry by firm 1: exporting to a sales agent (strategy 2) and FDI with a sales agent (strategy 10).

Off-shoring is a stronger option than out-sourcing. The final two columns of Table 8 show that four of the eight undominated strategies involve off-shoring production or $\mathrm{R} \& \mathrm{D}$, rather than just two as before. Off-shoring of $\mathrm{R} \& \mathrm{D}$ is effected by offshore licensing (strategy 4), licensing (strategy 12) and full integration by firm 2 (strategies 8 and 16). Two of these strategies (12 and 16) involve the transfer of knowledge from country 1 to country 2, whilst the other two leave knowledge in country 1 .

Off-shoring of distribution is effected by exporting (strategies 1 and 2) and strategies 9 and 10 (import-substituting FDI). These are classic IB market-seeking strategies in which production is owned by country 1 . There are also four dominated strategies that off-shore distribution.

The relationship between out-sourcing and off-shoring is summarised in Table 9. It focuses on the undominated strategies. It shows that R\&D can be off-shored and out-sourced at the same time, and that the same is true of distribution. However, R\&D is never off-shored when distribution is out-sourced, and distribution is never offshored when $R \& D$ is outsourced. Conversely, $R \& D$ is never out-sourced when distribution is off-shored, and distribution is never out-sourced when R\&D is off- 
shored. Either distribution or R\&D is always off-shored, but in four of the eight cases there is no out-sourcing of either activity.

In general, these results reflect the basic economic logic of out-sourcing and off-shoring. Out-sourcing foregoes the benefits of internalisation, whereas off-shoring does not. Off-shoring is a logical response to cost differentials between locations and it is efficient to exploit such differentials whether internalisation is used or not. Some of the specific results, however, also reflect the strict assumptions made about the number of different activities (only three) and the number of countries (only two).

\section{Inward and outward FDI}

FDI occurs when a facility is owned by a foreign-headquartered firm, and multinationality when a firm owns facilities in more than one country. Care is needed when discussing FDI because the "host" country that receives the investment is not necessarily the country whose market is served (country 2). Furthermore, the relationship between FDI and multinationality is not so simple as often supposed. A firm that undertakes FDI is not necessarily multinational because it may invest in a single foreign country and operate no domestic facility - in other words, it may be a “free-standing firm" (Wilkins, 1988). Free-standing firms appear naturally in supply chain models because there is no restriction that a firm must own a facility in the country in which it is headquartered.

In the model above six of the sixteen strategies involve free-standing firms. Strategies 3 and 14 involve free-standing FDI in production, strategy 5 free-standing FDI in R\&D, and strategy 7 free-standing FDI in distribution. Strategies 7 and 13 are particularly notable, because the entire supply chain is coordinated by free-standing firms - one based in each country. In each case one of the firms owns an integrated 
operation in the foreign country; under strategy 7 firm 2 integrates $R \& D$ and production in country 1 , while under strategy 13 firm 1 integrates production and distribution in country 2 . Because all these strategies are dominated, however, freestanding firms do not appear in the solution; the model therefore predicts correctly that free-standing firms - though logically possible - do not normally occur. Freestanding firms normally appear only when coordination costs vary according to the country in which the firm is headquartered - a feature of the investments identified in Wilkins's research. The model can, however, be readily extended to examine this case.

The patterns of FDI associated with undominated activities are analysed in Table 10. The first two columns indicate which activity is foreign-owned, and the home country in which the investor is headquartered. Six of the eight strategies involve some form of FDI. Each firm undertakes FDI on three occasions: thus there is no bias in the model towards firm 1 undertaking the FDI. This is in marked contrast to popular expositions of FDI theory, which suggest that it is the norm for firm 1 to undertake FDI. In the light of the previous discussion, it could be said that "assetseeking” FDI is, in principle, just as efficient as “market-seeking” FDI in serving a foreign market. There are two strategies which involve no FDI: exporting to a sales subsidiary (strategy 2) and licensing (strategy 12); in these cases supply chain coordination is undertaken entirely by domestic firms.

The two firms never undertake FDI at the same time, so there are no crossflows of investment. The last two columns show that FDI is always undertaken by an MNE. With only three activities to coordinate, both firms cannot be MNEs at the same time. In some cases the MNE owns the entire chain and in other cases only a 
part of it. Where an MNE partly owns a supply chain, it integrates either upstream $-R$ and $P$ - or downstream $-P$ and $D$ - but never just the beginning, $R$, and the end, $D$.

This contrasts markedly with the dominated strategies, where all involve FDI. Furthermore, six of the eight strategies involve both firms undertaking FDI. A hallmark of the dominated strategies, therefore, is that levels of FDI are excessive. FDI is excessive because the benefits of internalisation are purchased at too great a cost of foreign ownership. This observation affords an interesting perspective on the view in some of the FDI literature that FDI is often a superior strategy.

\section{The dualistic view of supply chain strategy}

It was noted above that some of the supply chain strategies could be described in more than one way. Where two firms participate in the same supply chain, strategy can be described from either firm's point of view. Only with full integration, where only one firm is involved, is the description of strategy unambiguous. For example, if firm 1 exports to its own distribution subsidiary (strategy 1) then "exporting" is obviously the strategy. But if firm 1 exports to an independent sales agent, namely firm 2, then firm 2's strategy is to import from an integrated foreign supplier. The arguments in favour of firm 1's perspective is that firm 1 undertakes the FDI, it is the only firm to internalise, and it undertakes the R\&D. The argument in favour of firm 2's perspective is that it is based in the country 2 and owns a distribution facility there, and therefore knows the market best.

In many cases the ambiguity is more serious. Consider, for example, licensing (strategy 12). From firm 1's point of view, the strategy is to enter a foreign market by licensing to firm 2, whilst from firm 2's point of view it is to out-source and off-shore R\&D. The argument for firm 1's point of view is that it owns $R \& D$, while the 
argument for firm 2's point of view is that it is the only firm to internalise (it integrates production and distribution) and it is based in the market being served. Appealing to FDI is indecisive because neither firm undertakes FDI. In favour of firm 1 , it could be argued that as it owns R\&D it controls the development of the technology and hence determines the technology that is licensed, but in favour of firm 2 in could be said that it knows the market best and can therefore specify the technology that must be developed; it therefore controls the development of the technology through the terms of the licensing agreement, in which it pre-purchases the specific technology that it requires.

Table 11 describes each of the sixteen strategies from the standpoint of each firm. Apart from full integration (strategies 1, 8, 9 and 16), all strategies can be viewed from two perspectives. Furthermore, for every strategy in which one firm appears to take a leading role, there is another strategy in which the roles are effectively interchanged and the other firm appears to take the more pro-active role. These symmetries involving strategies are characteristic of supply chain analysis, and tend to be overlooked by a firm-centred view.

No consistent view of strategy formation can be found in the IB literature. Innovation theorists tend to argue that strategy formation is linked to ownership of $\mathrm{R} \& \mathrm{D}$; marketing theorists that proximity to the customer is key, thereby placing strategy formation at opposite end of the supply chain (Buckley and Casson, 2011); while Dunning's eclectic theory suggests that strategy formation is linked to FDI, and that licensing is a less strategic option. Supply chain analysis takes no particular view on these issues. By assuming that the overall profit of the chain is maximised, it leaves open the question of how profit is divided. While all the monopoly profit may well be appropriated by the firm that formulates the strategy, no assumption is made 
about which firm that will be. While it predicts the total profit generated by the chain, the theory does not predict how the profit will be divided, either between participating firms or particular stages of the chain. The distribution of profit will reflect the terms of the contracts negotiated between participating firms, which are not predicted by the model.

\section{Applications and extensions}

The systems view of IB has a long intellectual pedigree that can be traced back to the inter-war period. Several of the supply chain trade-offs identified above have been recognised in empirical applications of IB theory for many years. Foreman-Peck (1986), for example, analysed the supply chain for automobile engines in terms of internalisation and location, while Read (1986) analysed the interplay between differential production location costs and the cost of foreign ownership in the synthetic fibres industry. Development economists have also examined these tradeoffs, with special reference to technology transfer to low-wage countries (Helleiner, 1981). Their relevance to the optimisation of development strategy is discussed in UNCTAD (2011), where a large amount of recent supply chain literature is reviewed.

The trade-off between internalising supply chain linkages through a firm headquartered in the host market (firm 2) rather in the country where R\&D is based (firm 1) helps to explain the growing importance of asset-seeking investments in hightechnology industries. In particular, the falling cost of foreign ownership of R\&D means that it is now much more viable than before for firms headquartered in major markets where indigenous technological capability is still developing to acquire R\&D facilities in technologically advanced economies (e.g. Chinese investment in the US and Indian investment in the UK). As Buckley and Casson (2011) suggest, this may explain why technology is becoming "commodified", and firm advantages are 
increasingly seen to lie with marketing-led firms headquartered in certain types of emerging market - namely developing countries with large populations. The relative decline of the traditional model of market-seeking FDI and the rise of asset-seeking FDI are therefore "two sides of the same coin", as are the decline of traditional headquarters countries and rise of new headquarters countries amongst the emerging market economies.

The model presented above helps to bridge the gap between firm-specific case studies (e.g. Ivarsson and Alvstam, 2010) and the general equilibrium models favoured by trade theorists (Grossman and Helpman, 2005; Grossman and RossiHansberg, 2008). As a model of supply chain equilibrium within an industry, it links both with intra-industry analysis of supply chain coordination and inter-industry analysis of trade.

The model can be extended in various ways. For example, it could be used to formalise some of the insights in Mudambi's (2008) analysis of fine-slicing and the distribution of value added within the supply chain; although Mudambi presents profit functions for alternative supply chain configurations, he does not solve his model explicitly. The model could also be used to analyse the impact of headquarters location on supply chain efficiency; this would involve introducing location-specific costs of headquarters operation, making it possible to address the topical issue of stand-alone headquarters. Such a model could explain why free-standing firms, "hollow firms" and "network firms" emerge in certain industries at certain times (see Contractor, Kumar, Kundu and Pedersen, 2010).

There is an important qualification, however. The model presented above is the most sophisticated model of its type that possesses a straightforward closed-form 
analytical solution that can be explained in intuitive terms. Although more complex models can be devised, their solutions are extremely complicated. Every time a new dimension of variation is introduced into the model, the number of possible strategies doubles, from sixteen to thirty-two to sixty-four, and so on.

It is, however, possible to alter the specification of the model without increasing its dimensions. Instead of footloose production, for example, footloose $\mathrm{R} \& \mathrm{D}$ can be introduced. Introducing an additional stage of production makes it possible to analyse more complex ownership issues, provided that all locations are fixed. Alternatively, by fixing some of the ownership arrangements the model can be generalised to three locations in order to analyse Triad effects, and linkages between countries at different stages of development. While the basic principles of the model will remain unchanged, altering the context will change the predictions.

Another possibility is to increase the number of dimensions but to introduce additional constraints at the same time. It is possible to assume a multi-level division of labour in which different types of activity, such as production, distribution and $\mathrm{R} \& \mathrm{D}$, are resolved into sub-systems of inter-dependent constituent activities. If each constituent activity interacts only with other activities of the same type then the model can be solved in two stages. Each sub-system is optimised conditional on the configuration of the system as a whole, and the system as a whole is then optimised on the basis that each sub-system will adapt to the overall configuration.

Another approach is to use a different method of solution. If a hierarchy of sub-systems cannot be assumed, for example, then the model can be solved through numerical simulation instead. This establishes a useful agenda for future research.

\section{Conclusions}


This paper has presented a model of supply chain coordination in which four strategic decisions are involved: the ownership of three activities - R\&D, production and distribution - and the location of one of them - production. The interdependencies between the ownership decisions, and between ownership and location decisions, have all been examined. It is shown that where the benefits of internalisation are positive, only half of the possible supply chain strategies are viable.

Efficiency is analysed from the perspective of the supply chain as a whole rather than any individual firm. Indeed, it is impossible to determine whether any firm of a given type (i.e. comprising a given structure of activities) will actually exist until the overall structure of the chain is determined. When a systems view is adopted, firms become endogenous institutions that emerge in specific configurations under specific circumstances. Unlike the firm-centred view, the existence of any specific type of firm cannot be taken as a given.

The circumstances that govern the emergence of firms are captured by the basic parameters of the model. There are four sets of parameters, which between them govern the resource costs and communication costs of the system, and include the costs of both the activities and their linkages. These parameters represent the economic fundamentals of the relevant industry. Ownership structures depend mainly on coordination costs and location strategies mainly on resource costs. There are interdependencies, however, which arise because of the costs of foreign ownership; the lower these costs, the more separable the ownership and location decisions become.

Where partnerships develop, the terms of the partnership will reflect the negotiating strategies of the firms, and the outcome of these negotiations will 
determine the distribution of profit between the firms. A firm with a monopoly of a technology has the greatest bargaining power, but this is not necessarily the firm that carries out the $R \& D$; where technologies are easy to specify and there are competing $R \& D$ facilities, a firm that is close to the market and alert to opportunities (i.e. firm 2) may acquire a technology at cost and thereby appropriate the rents.

The systems view is not intended to replace the firm-centred view, but rather to complement it. The firm-centred view has intuitive appeal for business students and managers because it focuses on issues of immediate concern to them. It fits well with the notion that IB theory exists to advise managers about devising and implementing internationalisation strategies. The firm-centred view, however, affords only a partial and localised view of the firm's environment that is predicated on given market opportunities, given cost conditions, and given competitive rivalries.

The systems view, by contrast, analyses long-run global issues rather than short-run local issues. It takes very little as given. In the long run certain types of firm may no longer be viable, because of changes in the global system, and for such firms the only question may be to optimise their exit strategy. The threat that these firms face may come, not from their existing competitors, but from future competitors, including firms that have not yet been founded. Unlike the firm-centred view, the systems view can identify opportunities for new types of firm. The key strategic decisions relating to these firms will be taken by start-up entrepreneurs before their firms have even been founded, but the legacy of these decisions may live on within the corporate cultures of the successful start-up firms.

Where existing firms survive, they may find that in future their roles are radically changed - e.g. they may become subcontractors to firms to which they 
previously subcontracted. While they may wish that they could continue to hold the initiative, competitive conditions may dictate otherwise, and the only alternative to accepting a subordinate role may be to fail altogether. The systems view can help such firms to understand the economic logic of their altered circumstances, and to make the necessary adjustments before it is too late. Using the systems view, it is possible to analyse, not only responses to given changes in the environment, but to analyse the fundamental drivers of change itself. 


\section{References}

Adler, N. and Hashai, N. (2007) Knowledge flow and the modelling of the multinational enterprise, Journal of International Business Studies, 38(4), pp. 639657.

Antras, P. and Helpman, E. (2004) Global sourcing, Journal of Political Economy, 112, pp.552-580.

Barney, J.B. and Clark, D.N. (2007) Resource-based Theory (Oxford: Oxford University Press)

Birkinshaw, J.M. and Young, S. (2005) Subsidiary entrepreneurship, internal and external competitive forces and subsidiary performance, International Business Review, 14(2), pp. 227-248.

Buckley, P.J. and Casson, M. (1976) The Future of the Multinational Enterprise (London: Macmillan).

Buckley, P.J. and Casson, M. (1998) Analysing foreign market entry strategies: Extending the internalization approach, Journal of International Business Studies, 29(3), pp. 539-561.

Buckley, P.J. and Casson, M. (2011) Marketing and the multinational, Journal of the Academy of Marketing Science, 39(2), pp.492-508.

Buckley, P.J. and Ghauri, P.N. (2004) Globalisation, economic geography and the strategy of multinational enterprises, Journal of International Business Studies, 35(2), pp. 81-98.

Buckley, P.J. and Hashai, N. (2004) A global system view of firm boundaries, Journal of International Business Studies, 53(1), pp. 33-45.

Cantwell, J.A. and Mudambi, R. (2005) MNC competence-creating subsidiary mandates, Strategic Management Journal, 26(12), pp. 1109-1128.

Carlson, S. (1939) A Study of the Pure Theory of Production (Stockholm: Swedish School of Economics)

Casson, M. (1990) Enterprise and Competitiveness: A Systems View of International Business (Oxford: Clarendon Press).

Casson, M. (1985) Multinationals and Intermediate Product Trade, in Buckley, P.J. and Casson, M.C., Economic Theory of the Multinational Enterprise, pp. 144-171, (London: Macmillan)

Casson, M. and Wadeson, N.S. (2012) The economic theory of international business: A supply chain perspective, Multinational Business Review, 20(2), 114-134.

Coase, R.H. (1937) The nature of the firm, Economica, New series, 4(4), pp. 386-405. Contractor, F., Kumar, V., Kundu, S. and Pedersen, T. (2010) Reconceptualising the firm in a world of outsourcing and offshoring: The organisational and geographical relocation of high-value company function, Journal of Management Studies, 47(8), pp.1417-1433.

di Gregorio, D., Musteena, M., and Thomas, D.E. (2009) Offshore outsourcing as a source of international competitiveness for SMEs, Journal of International Business Studies, 40(6), pp. 969-988.

Dunning, J.H. (1977) Trade, location of economic activity and the multinational enterprise: The search for an eclectic approach, in Ohlin, B., Hesselborn, P.O., and Wijkman, P.M. (Eds), The International Allocation of Economic Activity, pp. 395-418 (London: Macmillan).

Dunning, J.H. and Lundan, S. (2008) Multinational Enterprises and the Global Economy (Cheltenham: Edward Elgar).

Foreman-Peck, J. (1986) The motor industry, in Casson, M.C. (ed.) Multinationals and World Trade, pp.141-173, (London: Allen \& Unwin). 
Frobel, F., Heinrichs, J. and Kreye, O. (1980) The New International Division of Labour (Cambridge: Cambridge University Press).

Grossman, G.M. and Helpman, E. (2005) Outsourcing in a global economy, Review of Economic Studies, 72, pp. 135-159.

Grossman, G.M. and Rossi-Hansberg, E. (2008) Trading tasks: A simple theory of offshoring, American Economic Review, 98 (5), pp.1978-1997

Helleiner, G.K. (1981) Intra-firm Trade and the Developing Countries (London:

Macmillan).

Hennart, J.-F. (1982) A Theory of Multinational Enterprise (Ann Arbor: University of Michigan Press).

Ivarsson, I. and Alvstam, C.G. (2010) Supplier upgrading in the home-furnishing value chain: an empirical study of IKEA's sourcing in China and South East Asia, World Development, 38 (11), 1575-1587.

Kotabe, M. and Mol, M.J. (2006) Global Supply Chain Management (Cheltenham:

Edward Elgar).

Lerner, A.P. (1953) Essays in Economic Analysis, London: Macmillan

Miroudot, S., Lan, R. and Ragoussis, A. (2009) Trade in intermediate goods and services, (Paris: OECD, Trade Policy Working Paper 93)

Mol, M. (2007) Outsourcing: Design, Process, Performance (Cambridge: Cambridge University Press).

Mudambi, R. (2008) Location, control and innovation in knowledge-intensive industries, Journal of Economic Geography, 8 (5), pp.699-725

Mudambi, R. and Venzin, M. (2010) The strategic nexus of offshoring and outsourcing decisions, Journal of Management Studies, 47(8), pp. 1510-1533.

Porter, M.E. (1980) Competitive Strategy (New York: Free Press)

Read, R.A. (1986) The synthetic fibre industry, in Casson, M.C. (ed.) Multinationals and World Trade, pp.197-223, (London: Allen \& Unwin).

Rugman, A.M. (1981) Inside the Multinationals: The Economics of Internal Markets (London: Routledge).

Sturgeon, T., van Biesebroeck, J. and Gereffi, G. (2008) Value chains, networks and clusters: Reframing the global automotive industry, Journal of Economic Geography, 8(3), pp.297-321.

UNCTAD (2011) World Investment Report 2011: Non-equity Modes of International Production and Development, (Geneva: UN)

Wilkins, M. (1988) The free-standing company, 1870-1914: An important type of British foreign direct investment, Economic History Review, 41 (2), pp.259-282. 
Table 1. Classification of costs in the model

\begin{tabular}{|c|c|c|c|}
\hline & \multicolumn{2}{|l|}{ Type of Activity } \\
\hline & & Plant & Linkage \\
\hline \multirow[t]{2}{*}{$\begin{array}{l}\text { Type of } \\
\text { Cost }\end{array}$} & Resource & $\begin{array}{l}\text { Cost of local } \\
\text { production in countries } \\
1 \text { and } 2, c_{1}, c_{2}>0\end{array}$ & $\begin{array}{l}\text { Trade costs: Transport, } \\
\text { tariff and compliance costs } \\
\text { incurred by exports or } \\
\text { imports (symmetrical by } \\
\text { country), } t \geq 0 \\
\text { Technology transfer cost } \\
\text { from country } 1 \text { to country } \\
2, x>0\end{array}$ \\
\hline & Coordination & $\begin{array}{l}\text { Cost premium of } \\
\text { foreign ownership of } \\
\text { production or } \\
\text { distribution } \\
\text { (symmetrical by } \\
\text { country), } f \geq 0 \\
\text { Cost premium of } \\
\text { foreign ownership of } \\
R \& D, g \geq f \geq 0\end{array}$ & $\begin{array}{l}\text { Cost of arm's length trade: } \\
\text { the internalisation benefit } \\
\text { for wholesale market, } k>0 \\
\text { Cost of licensing: the } \\
\text { internalisation benefit for } \\
\text { knowledge transfer } \\
\text { foregone, } n>0 \\
\text { Differential marketing cost: } \\
\text { Cost to a distributor owned } \\
\text { in country } 1 \text { of selling in } \\
\text { country } 2, m>0\end{array}$ \\
\hline
\end{tabular}


Table 2. Ownership decisions for R\&D, production and distribution facilities, coupled with a location decision for a production facility

\begin{tabular}{|c|c|c|c|c|c|}
\hline $\begin{array}{l}\text { Strategy: } \\
\text { Number and } \\
\text { Descriptor }\end{array}$ & $\begin{array}{l}\text { Location } \\
\text { of } \\
\text { Prod'n }\end{array}$ & $\begin{array}{l}\text { Own'ship } \\
\text { of R\&D }\end{array}$ & $\begin{array}{l}\text { Own'ship } \\
\text { of } \\
\text { Prod'n }\end{array}$ & $\begin{array}{l}\text { Own'ship } \\
\text { of Distr'n }\end{array}$ & Cost \\
\hline $\begin{array}{l}\text { 1. Export to } \\
\text { sales subsidiary }\end{array}$ & 1 & 1 & 1 & 1 & $C_{1}=c_{1}+t+m+f$ \\
\hline $\begin{array}{l}\text { 2. Export to } \\
\text { sales agent }\end{array}$ & 1 & 1 & 1 & 2 & $C_{2}=c_{1}+t+k$ \\
\hline $\begin{array}{l}\text { 3. FDI in } \\
\text { distribution } \\
\text { with } \\
\text { subcontracting } \\
\text { to foreign- } \\
\text { owned local } \\
\text { plant }\end{array}$ & 1 & 1 & 2 & 1 & $\begin{array}{l}C_{3}=c_{1}+t+k+n+m+ \\
2 f\end{array}$ \\
\hline $\begin{array}{l}\text { 4. Offshore } \\
\text { licensing }\end{array}$ & 1 & 1 & 2 & 2 & $C_{4}=c_{1}+t+n \quad+f$ \\
\hline $\begin{array}{l}\text { 5. Export to } \\
\text { sales subsidiary } \\
\text { with } \\
\text { subcontracting } \\
\text { to local foreign- } \\
\text { owned R\&D } \\
\text { facility }\end{array}$ & 1 & 2 & 1 & 1 & $\begin{array}{l}C_{5}=c_{1}+t+n+m+f+ \\
g\end{array}$ \\
\hline $\begin{array}{l}\text { 6. Host-country } \\
\text { MNE } \\
\text { subcontracts } \\
\text { off-shore } \\
\text { production }\end{array}$ & 1 & 2 & 1 & 2 & $C_{6}=c_{1}+t+k+n+g$ \\
\hline $\begin{array}{l}\text { 7. FDI in } \\
\text { distribution } \\
\text { with out- } \\
\text { sourced } \\
\text { production and } \\
\text { R\&D }\end{array}$ & 1 & 2 & 2 & 1 & $\begin{array}{l}C_{7}=c_{1}+t+k+m+2 f \\
+g\end{array}$ \\
\hline $\begin{array}{l}\text { 8. Fully } \\
\text { integrated host- } \\
\text { country MNE } \\
\text { off-shores } \\
\text { production and } \\
\text { R\&D }\end{array}$ & 1 & 2 & 2 & 2 & $C_{8}=c_{1}+t+f+g$ \\
\hline $\begin{array}{l}\text { 9. Import- } \\
\text { substituting FDI } \\
\text { in production } \\
\text { and sales }\end{array}$ & 2 & 1 & 1 & 1 & $C_{9}=c_{2}+x+m+2 f$ \\
\hline
\end{tabular}




\begin{tabular}{|c|c|c|c|c|c|}
\hline $\begin{array}{l}\text { 10. Import- } \\
\text { substituting FDI } \\
\text { in production } \\
\text { with sales agent }\end{array}$ & 2 & 1 & 1 & 2 & $C_{10}=c_{2}+x+k+f$ \\
\hline $\begin{array}{l}11 \text { FDI in sales } \\
\text { with } \\
\text { subcontracted } \\
\text { production to } \\
\text { foreign-owned } \\
\text { local plant }\end{array}$ & 2 & 1 & 2 & 1 & $\begin{array}{l}C_{11}=c_{2}+x+k+n+m \\
+f\end{array}$ \\
\hline 12. Licensing & 2 & 1 & 2 & 2 & $C_{12}=c_{2}+x+n$ \\
\hline $\begin{array}{l}13 . \text { Host- } \\
\text { country firm } \\
\text { licenses a } \\
\text { source-country } \\
\text { firm }\end{array}$ & 2 & 2 & 1 & 1 & $\begin{array}{l}C_{13}=c_{2}+x+m+n+2 f \\
+g\end{array}$ \\
\hline $\begin{array}{l}\text { 14. Host- } \\
\text { country MNE } \\
\text { subcontracts } \\
\text { production in } \\
\text { host country to } \\
\text { foreign firm }\end{array}$ & 2 & 2 & 1 & 2 & $\begin{array}{l}C_{14}=c_{2}+x+k+n+f+ \\
g\end{array}$ \\
\hline $\begin{array}{l}15 . \text { Host- } \\
\text { country MNE } \\
\text { subcontracts } \\
\text { distribution to } \\
\text { foreign firm }\end{array}$ & 2 & 2 & 2 & 1 & $\begin{array}{l}C_{15}=c_{2}+x+k+m+f+ \\
g\end{array}$ \\
\hline $\begin{array}{l}\text { 16. Fully } \\
\text { integrated host } \\
\text { country MNE } \\
\text { off-shores R\&D }\end{array}$ & 2 & 2 & 2 & 2 & $C_{16}=c_{2}+x+g$ \\
\hline
\end{tabular}

Note: $C_{j}$ denotes the cost of strategy $j(j=1, \ldots, 16) . c_{1}$ : cost of production in country $1 ; c_{2}$ : cost of production in country $2 ; t$ : trade-related cost; $x$ : technology transfer cost; $n$ : licensing cost; $k$ : cost of arm's length trade; $m$ : cost of foreign marketing; $f$ : cost of foreign ownership of production; $g$ : cost of foreign ownership of R\&D.

In Tables 1 - 8 'host country' refers to country 2. Note, however, that if firm 2 invests in country 1 then country 1 would be the 'host' so far as the FDI was concerned. Using the systems view, the terms 'source' and 'host' must be used with care. 
Table 3. Simplified cost structures of undominated strategies

\begin{tabular}{|c|c|}
\hline Strategy & Simplified Cost \\
\hline 1. Export to sales subsidiary & $C_{1}=C_{0}+d \quad+m \quad+f$ \\
\hline 2. Export to sales agent & $C_{2}=C_{0}+d+k$ \\
\hline 4. Offshore licensing & $C_{4}=C_{0}+d$ \\
\hline $\begin{array}{l}\text { 8. Fully-integrated host- } \\
\text { country MNE off-shores } \\
\text { production and R\&D }\end{array}$ & $C_{8}=C_{0}+d$ \\
\hline $\begin{array}{l}\text { 9. Import-substituting FDI } \\
\text { in production and sales }\end{array}$ & $+m \quad+2 f$ \\
\hline $\begin{array}{l}\text { 10. Import-substituting FDI } \\
\text { in production with sales } \\
\text { agent }\end{array}$ & $C_{10}=C_{0} \quad+k$ \\
\hline 12. Licensing & $C_{12}=C_{0}$ \\
\hline $\begin{array}{l}\text { 16. Fully-integrated host- } \\
\text { country MNE off-shores } \\
\text { R\&D }\end{array}$ & $C_{16}=C_{0}$ \\
\hline
\end{tabular}

Note: $C_{0}=c_{2}+x ; d=c_{1}-c_{2}+t-x$. 
Table 4. Inequality conditions that identify the least cost strategy from amongst the undominated strategies

\begin{tabular}{|c|c|c|c|c|c|c|c|c|}
\hline & 1 & 2 & 4 & 8 & 9 & 10 & 12 & 16 \\
\hline 1 & - & $k-m-f$ & $n-m$ & $g-m$ & $-d+f$ & $-d+k-m$ & $\begin{array}{l}-d+n-m \\
-f\end{array}$ & $\begin{array}{l}-d-m- \\
f+g\end{array}$ \\
\hline 2 & $\begin{array}{l}-k+m \\
+f\end{array}$ & - & $-k+n+f$ & $-k+f+g$ & $\begin{array}{l}-d-k \\
+m+2 f\end{array}$ & $-d+f$ & $-d-k+n$ & $-d-k+g$ \\
\hline 4 & $m-n$ & $k-n-f$ & - & $g-n$ & $\begin{array}{l}-d+m \\
-n+f\end{array}$ & $-d+k-n$ & $-d-f$ & $-d-f+g-n$ \\
\hline 8 & $m-g$ & $k-f-g$ & $n-g$ & - & $\begin{array}{l}-d+m+ \\
f-g\end{array}$ & $-d+k-g$ & $\begin{array}{l}-d+n-f \\
-g\end{array}$ & $-d-f$ \\
\hline 9 & $d-f$ & $\begin{array}{l}d+k-m \\
-2 f\end{array}$ & $\begin{array}{l}d-m+n \\
-f\end{array}$ & $\begin{array}{l}d-m-f \\
+g\end{array}$ & - & $k-m-f$ & $\begin{array}{l}-m+n- \\
2 f\end{array}$ & $\begin{array}{l}-m-2 f \\
+g\end{array}$ \\
\hline 10 & $d-k+m$ & $d-f$ & $d-k+n$ & $d-k+g$ & $\begin{array}{l}-k+m \\
+f\end{array}$ & - & $-k+n-f$ & $-k-f+g$ \\
\hline 12 & $\begin{array}{l}d-n+m \\
+f\end{array}$ & $d+k-n$ & $d+f$ & $\begin{array}{l}d-n+f \\
+g\end{array}$ & $m-n+2 f$ & $k-n+f$ & - & $-n+g$ \\
\hline 16 & $\begin{array}{l}d+m+f- \\
g\end{array}$ & $d+k-g$ & $\begin{array}{l}d+f- \\
g+n\end{array}$ & $d+f$ & $m+2 f-g$ & $k+f-g$ & $n-g$ & - \\
\hline
\end{tabular}

Note: Each cell indicates the cost saving afforded by the row strategy relative to the column strategy. The expression in each cell must be non-negative if the row strategy is to be preferred to the column strategy. By construction, the diagonal terms are zero, and the off-diagonal terms are equal in magnitude but opposite in sign when reflected in the main diagonal. To solve them, therefore, it is sufficient to use either the cells to the north-east of the main diagonal or the cells to the south-west of it. The cells are shown in four blocks: the top left-hand block reports differentials between pairs of strategies which both involve production in country 1; the bottom right-hand block relates to strategies that both involve production in country 2 ; whilst the off-diagonal blocks relate to pairs of strategies that involve production in different countries. 
Table 5. Solution of the model

\begin{tabular}{|l|l|l|l|}
\hline Strategy & $\boldsymbol{d} \leq-\boldsymbol{f}$ & $\boldsymbol{- f \leq \boldsymbol { d } \leq \boldsymbol { f }}$ & $\boldsymbol{d} \geq \boldsymbol{f}$ \\
\hline 1 & $m \leq k-f, n, g$ & $m+f \leq k, n-d, g-d$ & \\
\hline 2 & $k-f \leq m, n, g$ & $k \leq m+f, n-d, g-d$ & \\
\hline 4 & $n \leq m, k-f, g$ & & \\
\hline 8 & $g \leq m, k-f, n$ & & $m+2 f \leq k+f, n, g$ \\
\hline 9 & & & $k+f \leq m+2 f, n, g$ \\
\hline 10 & & & \\
\hline 12 & & $n-d \leq m+f, k, g-d$ & $n \leq m+2 f, k+f, g$ \\
\hline 16 & & $g-d \leq m+f, k, n-d$ & $g \leq m+2 f, k+f, n$ \\
\hline
\end{tabular}

Note: In the north-east block, the diagonal term in the top row indicates that strategy 1 is preferred to strategy 9 when $d \leq f$, and conversely that 9 is preferred to 1 when $d \geq$ $f$. Similarly the diagonal term in the second row indicates that strategy 2 is preferred to strategy 10 when $d \leq f$, and that strategy 10 is preferred to strategy 2 when $d \geq f$. The diagonal term in the third row implies that strategy 4 is preferred to strategy 12 when $d \leq-f$, and that strategy 12 is preferred to strategy 4 when $d \geq-f$, while the diagonal term in the fourth row implies that strategy 8 is preferred to strategy 16 when $d \leq-f$, and that strategy 16 is preferred to strategy 8 when $d \geq-f$.

Now $f \geq 0, d \geq f$ implies that $d \geq-f$ and $d \leq-f$ implies that $d \leq f$. Hence when $d \leq-$ $f$ strategy 1 is preferred to strategy 9,2 to 10,4 to 12 and 8 to 16 ; thus only strategies $1,2,4$ and 8 are viable. Conversely, when $d \geq f 9$ is preferred to 1,10 to 2,12 to 4 and 16 to 8 , so that only strategies 9,10, 12 and 16 are viable. Finally, if $-f<d<f$ then strategy 1 is preferred to 9,2 to 10,12 to 4 and 16 to 8 ; thus only strategies 1,2 , 12 and 16 are viable. Thus when $d \leq-f$ it is sufficient to compare strategies $1,2,4$ and 8 in order to determine which is best; when $d \geq f$ it is sufficient to compare strategies $9,10,12$ and 16, whilst when $-f \leq d \leq f$ it is sufficient to compare strategies $1,2,12$ and 16.

In the top half of the table all the terms in row 1 (other than the north-east diagonal term referred to above) involve the parameter $m$, all the analogous terms in row 2 involve $k$, all the analogous terms in row 3 involve $n$ and all the analogous terms in row 4 involve $g$; and the same pattern is repeated in the bottom half of the table. 
Table 6. Simplified solution of the model

\begin{tabular}{|l|l|l|l|}
\hline Strategy & $\boldsymbol{d} \leq-\boldsymbol{f}$ & $\boldsymbol{- f} \leq \boldsymbol{d} \leq \boldsymbol{f}$ & $\boldsymbol{d} \geq \boldsymbol{f}$ \\
\hline 1 & $m=z_{1}$ & $m+f=z_{3}$ & \\
\hline 2 & $k-f=z_{1}$ & $k=z_{3}$ & \\
\hline 4 & $n=z_{1}$ & & \\
\hline 8 & $g=z_{1}$ & & \\
\hline 9 & & & $m+2 f=z_{2}$ \\
\hline 10 & & & $k+f=z_{2}$ \\
\hline 12 & & $n-d=z_{3}$ & $n=z_{2}$ \\
\hline 16 & & $g-d=z_{3}$ & $g=z_{2}$ \\
\hline
\end{tabular}

Note: $z_{1}=\min [m, k-f, n, g] ; z_{2}=\min [m+2 f, k+f, n, g]$; $z_{3}=\min [m+f, k, n-d, g-d]$ 
Table 7. The endogeneity of firms: the number of firms and the scope of their operations under alternative supply chain strategies

\begin{tabular}{|c|c|c|}
\hline \multirow[t]{2}{*}{ Strategy } & \multicolumn{2}{|c|}{ Scope of Firm's Operations } \\
\hline & Firm 1 & Firm 2 \\
\hline 1. Export to sales subsidiary & $\begin{array}{l}\text { Fully integrated MNE } \\
\text { exports to a wholly- } \\
\text { owned distribution } \\
\text { facility }\end{array}$ & \\
\hline 2. Export to sales agent & $\begin{array}{l}\text { Single-country firm } \\
\text { exports to an } \\
\text { independent foreign } \\
\text { distributor }\end{array}$ & $\begin{array}{l}\text { Single-country foreign } \\
\text { distributor imports from } \\
\text { country } 1\end{array}$ \\
\hline 4. Offshore licensing & $\begin{array}{l}\text { Single-country firm } \\
\text { licenses a foreign firm }\end{array}$ & $\begin{array}{l}\text { MNE acquires foreign } \\
\text { technology under license } \\
\text { and exports to a wholly- } \\
\text { owned foreign distribution } \\
\text { facility }\end{array}$ \\
\hline $\begin{array}{l}\text { 8. Fully-integrated host- } \\
\text { country MNE off-shores } \\
\text { production and R\&D }\end{array}$ & & $\begin{array}{l}\text { Fully integrated MNE } \\
\text { undertakes both production } \\
\text { and } R \& D \text { overseas }\end{array}$ \\
\hline $\begin{array}{l}\text { 9. Import-substituting FDI in } \\
\text { production and sales }\end{array}$ & $\begin{array}{l}\text { Fully integrated MNE } \\
\text { produces and sells } \\
\text { abroad }\end{array}$ & \\
\hline $\begin{array}{l}\text { 10. Import-substituting FDI } \\
\text { in production with sales } \\
\text { agent }\end{array}$ & $\begin{array}{l}\text { MNE produces abroad } \\
\text { and distributes through } \\
\text { an independent foreign } \\
\text { firm }\end{array}$ & $\begin{array}{l}\text { Single-country firm } \\
\text { distributes product } \\
\text { acquired from local } \\
\text { foreign-owned plant }\end{array}$ \\
\hline 12. Licensing & $\begin{array}{l}\text { Single-country firm } \\
\text { licenses a foreign firm }\end{array}$ & $\begin{array}{l}\text { Single-country firm } \\
\text { licenses a technology used } \\
\text { in local production and } \\
\text { distribution }\end{array}$ \\
\hline $\begin{array}{l}\text { 16. Fully-integrated host- } \\
\text { country MNE off-shores } \\
\text { R\&D }\end{array}$ & & $\begin{array}{l}\text { Fully integrated MNE } \\
\text { undertakes R\&D abroad } \\
\text { and produces and sells } \\
\text { locally }\end{array}$ \\
\hline
\end{tabular}


Table 8. Analysis of out-sourcing and off-shoring strategies

\begin{tabular}{|c|c|c|c|c|}
\hline \multirow[t]{2}{*}{ Strategy } & \multicolumn{2}{|c|}{ Out-source } & \multicolumn{2}{|c|}{ Off-shore } \\
\hline & R\&D & Distribution & R\&D & Distibution \\
\hline 1. Export to sales subsidiary & & & & $\mathrm{F}$ \\
\hline 2. Export to sales agent & & $\mathrm{F}$ & & $\mathrm{F}$ \\
\hline 4. Offshore licensing & $\mathrm{D}$ & & $\mathrm{D}$ & \\
\hline $\begin{array}{l}\text { 8. Fully-integrated host- } \\
\text { country MNE off-shores } \\
\text { production and R\&D }\end{array}$ & & & $\mathrm{D}$ & \\
\hline $\begin{array}{l}\text { 9. Import-substituting FDI in } \\
\text { production and sales }\end{array}$ & & & & $\mathrm{D}$ \\
\hline $\begin{array}{l}\text { 10. Import-substituting FDI } \\
\text { in production with sales } \\
\text { agent }\end{array}$ & & $\mathrm{D}$ & & $\mathrm{D}$ \\
\hline 12. Licensing & $\mathrm{F}$ & & $\mathrm{F}$ & \\
\hline $\begin{array}{l}\text { 16. Fully-integrated host- } \\
\text { country MNE off-shores } \\
\text { R\&D }\end{array}$ & & & $\mathrm{F}$ & \\
\hline $\begin{array}{l}\text { Total of dominating } \\
\text { strategies }\end{array}$ & 2 & 2 & 4 & 4 \\
\hline Total of dominated strategies & 6 & 6 & 4 & 4 \\
\hline Total & 8 & 8 & 8 & 8 \\
\hline
\end{tabular}

Note: D: Domestic linkage; F international linkage (involving export or import) 
Table 9. Relationship between out-sourcing and off-shoring for undominated strategies

\begin{tabular}{|l|l|l|l|}
\hline & \multicolumn{3}{|c|}{ Off-shoring } \\
\hline Out-sourcing & R\&D & Distribution & None \\
\hline R\&D & 4,12 & & \\
\hline Distribution & & 2,10 & \\
\hline None & 8,16 & 1,9 & \\
\hline
\end{tabular}

Note: The numbers that appear in the cells identify the strategies that fit the crossclassification. 
Table 10. Analysis of FDI stocks and MNE operations

\begin{tabular}{|l|l|l|l|l|}
\hline \multirow{2}{*}{ Strategy } & FDI & MNE \\
\cline { 2 - 5 } & Firm 1 & Firm 2 & Firm 1 & Firm 2 \\
\hline 1. Export to sales subsidiary & D & & R P D & \\
\hline 2. Export to sales agent & & & & \\
\hline 4. Offshore licensing & & P & & P D \\
\hline $\begin{array}{l}\text { 8. Fully-integrated host-country MNE off- } \\
\text { shores production and R\&D }\end{array}$ & & R P & & R P D \\
\hline $\begin{array}{l}\text { 9. Import-substituting FDI in production } \\
\text { and sales }\end{array}$ & P D & & R P D & \\
\hline $\begin{array}{l}\text { 10. Import-substituting FDI in production } \\
\text { with sales agent }\end{array}$ & P & & R P & \\
\hline 12. Licensing & & & & \\
\hline $\begin{array}{l}\text { 16. Fully-integrated host-country MNE } \\
\text { off-shores R\&D }\end{array}$ & & R & & R P D \\
\hline Total of dominating strategies & 3 & 3 & 3 & 3 \\
\hline Total of dominated strategies & 7 & 7 & 3 & 3 \\
\hline Total & 10 & 10 & 6 & 6 \\
\hline
\end{tabular}

Note: In columns 1 and $2 \mathrm{D}, \mathrm{P} \mathrm{R}$ denote FDI in distribution, production and R\&D respectively. Blank cells indicate no FDI. In columns 3 and $4 \mathrm{D}, \mathrm{P}, \mathrm{R}$ denote the activities owned and controlled by an MNE. Blank cells denote no MNE. 
Table 11. Perceptions of supply chain strategy by different participating firms

\begin{tabular}{|c|c|c|}
\hline $\begin{array}{l}\text { Strategy as Perceived by } \\
\text { Firm } 1\end{array}$ & $\begin{array}{l}\text { Strategy as Perceived by } \\
\text { Firm } 2\end{array}$ & $\begin{array}{l}\text { Symmetric Strategy } \\
\text { with Similar Location } \\
\text { of Production and } \\
\text { Interchanged } \\
\text { Ownership of Facilities }\end{array}$ \\
\hline 1. Export to sales subsidiary & NA & 16 \\
\hline 2. Export to sales agent & $\begin{array}{l}\text { Import from integrated } \\
\text { foreign producer }\end{array}$ & 15 \\
\hline $\begin{array}{l}\text { 3. FDI in distribution with } \\
\text { subcontracting to foreign- } \\
\text { owned local plant }\end{array}$ & $\begin{array}{l}\text { Free-standing FDI in } \\
\text { production (with out-sourced } \\
\text { R\&D and distribution) }\end{array}$ & 14 \\
\hline 4. Offshore licensing & $\begin{array}{l}\text { FDI with out-sourced off- } \\
\text { shore R\&D }\end{array}$ & 13 \\
\hline $\begin{array}{l}\text { 5. Export to sales subsidiary } \\
\text { with subcontracting to local } \\
\text { foreign-owned } R \& D \text { facility }\end{array}$ & $\begin{array}{l}\text { Free-standing FDI in R\&D } \\
\text { with licensing to foreign } \\
\text { exporter }\end{array}$ & 12 \\
\hline $\begin{array}{l}\text { 6. Export with out-sourced } \\
\text { R\&D and distribution }\end{array}$ & $\begin{array}{l}\text { FDI in R\&D with licensing to } \\
\text { foreign exporter }\end{array}$ & 11 \\
\hline $\begin{array}{l}\text { 7. Subcontracting production } \\
\text { and } R \& D \text { to an integrated } \\
\text { foreign firm }\end{array}$ & $\begin{array}{l}\text { Free-standing FDI with } \\
\text { integrated foreign production } \\
\text { and } R \& D\end{array}$ & 10 \\
\hline $8 . \mathrm{NA}$ & $\begin{array}{l}\text { Fully integrated FDI in R\&D } \\
\text { and production }\end{array}$ & 9 \\
\hline $\begin{array}{l}\text { 9. Fully integrated import- } \\
\text { substituting FDI in } \\
\text { production and sales }\end{array}$ & NA & 8 \\
\hline $\begin{array}{l}\text { 10. Import-substituting FDI } \\
\text { in production with sales } \\
\text { agent }\end{array}$ & $\begin{array}{l}\text { Procure from an integrated } \\
\text { inward investor }\end{array}$ & 7 \\
\hline $\begin{array}{l}11 \text { FDI in sales with } \\
\text { subcontracted production to } \\
\text { foreign-owned local plant }\end{array}$ & $\begin{array}{l}\text { Domestic production with } \\
\text { outsourced R\&D and } \\
\text { distribution }\end{array}$ & 6 \\
\hline 12. Licensing & $\begin{array}{l}\text { Domestic production and } \\
\text { distribution with out-sourced } \\
\text { R\&D }\end{array}$ & 5 \\
\hline $\begin{array}{l}\text { 13. Free-standing FDI with } \\
\text { out-sourced R\&D }\end{array}$ & $\begin{array}{l}\text { Free-standing FDI in R\&D } \\
\text { with licensing to exporter }\end{array}$ & 4 \\
\hline $\begin{array}{l}\text { 14.Free-standing FDI with } \\
\text { out-sourced R\&D and } \\
\text { distribution }\end{array}$ & $\begin{array}{l}\text { Free-standing FDI in R\&D } \\
\text { with subcontracted } \\
\text { production foreign-owned } \\
\text { local plant }\end{array}$ & 3 \\
\hline $\begin{array}{l}\text { 15. Host-country MNE } \\
\text { subcontracts distribution to } \\
\text { foreign firm }\end{array}$ & $\begin{array}{l}\text { Free-standing FDI with out- } \\
\text { sourced distribution }\end{array}$ & 2 \\
\hline 16. NA & FDI in $\mathrm{R} \& \mathrm{D}$ & 1 \\
\hline
\end{tabular}

